\title{
NEXUS OF MARKET RISK, DIVIDEND POLICY AND COMMERCIAL BANKS' PERFORMANCE IN SUB-SAHARAN AFRICA
}

\author{
Odunayo M. Olarewaju, Ph.D., Senior Lecturer \\ Durban University of Technology \\ Faculty of Accounting and Informatics \\ Department of Management Accounting \\ P.O. Box 1334, Durban, 4000, South Africa \\ e-mail: odunayoo@dut.ac.za \\ ORCID: 0000-0002-4366-040X
}

Received 12 December 2019, Accepted 26 September 2020

\begin{abstract}
Research Background: The concept of risk is of great importance in any financial system, due to unstable economic situations and fluctuating environmental factors. Like other variables, risk has a significant effect on firms' returns and profit.

Purpose: This study aims at examining the relationship between dividend policy and performance taking cognisance of the uncontrollable risk (market risk).

Research methodology: This study was modelled using 250 commercial banks from 30 selected SubSaharan African countries in the period 2008 to 2017. The Panel-Vector Error Correction Model was used to estimate the model.

Result: From the long run analysis, a long run relationship between dividend policy, agency cost, and bank performance is evident. The disequilibrium will take about $39.5 \%$ yearly speed of adjustment to return to a steady state. There is an inverse relationship between Lending interest rate (market risk proxy) with bank performance while there is a positive relationship of foreign exchange rate (market risk proxy) and bank performance in SSA.

Novelty: Market risk's influence on the relationship between dividend policy and bank performance was firstly established. Therefore, it is recommended that the banking sector in SSA should focus more on endogenous factors and review some of their policies as these contribute more significantly to variations in their performance than exogenous factors.
\end{abstract}

Keywords: Agency Cost, Sub-Saharan Africa, Impulse Response function, Variable Decomposition

JEL classification: G21, G35, B22, C33 


\section{Introduction}

Generally, everybody in modern society is familiar with the concept of risk because life itself is a risk. Traditionally, it means the consequences that could occur when the future is uncertain. Damodaran (2012) described risk using Chinese symbols as a mix of threats and opportunities. It has two perspectives; firstly, it can be regarded as any occurrence that strays from the results or returns predicted by an investor. Secondly, risk can be expressed as the probability of a decrease in the income expected from an investment (Gilb, 2002). The concept of risk is of great importance in any financial system, especially with regard to commercial banks that serve as intermediaries between the surplus and deficit units due to unstable economic situations and fluctuating environmental factors. Like other variables, risk has a significant effect on firms' returns and profit. A firm that successfully manages risk can overcome other economic or environmental challenges. According to the portfolio theory, Nimalathasan and Pratheepkanth (2012) there are two types of risk, systematic and non-systematic. A firm can control non-systematic risk such as credit risk, operational risk and liquidity risk through diversification, while systematic risk, also known as market risk (henceforth, MR), refers to the risk of changes in asset valuation due to uncontrollable factors known as outliers and cannot be controlled by the organisation. The relationship between risk and returns has long been a central focus of financial researchers that have concluded that investors are "risk-averse" and utility-maximisers (Collier, Agyei-Ampomah, 2006). They are always willing to diversify, and maximise utility so as to satisfy the desires of the dividend-oriented shareholders, but MR prevents diversification even though agency cost is inevitable. Due to the nature of MR, managers, investors, and scholars have investigated different ways to understand and manage it in order to sustain returns. Brigham and Ehrhardt (2013) concluded that a firm's major long-term goal is to deal with market or systematic risk. Hence, the managers of firms should ensure that MR is well managed. In a banking context, MR refers to the risk of losses in the bank's trading book caused by fluctuations in interest rates and foreign-exchange rates; unstable equity prices and credit spreads; dwindling commodity prices and similar factors outside the context of their system (Mehta, Neukirchen, Pfetsch, \& Poppensieker, 2012). However, as noted by Santomero (1997), two MRs are of major concern to banks, the interest rate risk and the foreign exchange risk, both of which have a significant impact on their performance. For instance, if banks fail to manage interest rate risk, their net interest margin will fall. Likewise, if the foreign exchange risk is not well managed, a bank will need to revalue its assets because currency fluctuations negatively influence its balance sheet. Therefore, this study sets to examine the relationship 
between the dividend policy, agency cost, MR and bank performance having known that MR is inevitable.

\section{Problem statement}

It has been established that there is no uniform dividend policy such that a particular policy that will genuinely boost the performance of banks have not been established. But the dividend payout ratio has been the most commonly adopted policy in most African firms, banking sector inclusive. Investors in the region are always willing to diversify, and to maximise utility so as to satisfy the desires of dividend-oriented shareholders, though agency cost is inevitable. The relationship between risk and returns has long been a central focus of financial researchers. They have investigated different ways to understand and manage it in order to sustain returns. Some of these scholars have examined risk in the context of commercial banks (Kargi, 2011; Musyoki, Kadubo, 2012; Fredrick, 2013; Li, Zou, 2014). However, these studies focused on bank-specific (unsystematic) risks such as liquidity and credit risk. The fact that interest and foreign exchange risk are the components of MR that are of major concern to banking sector foretells the quest to know the relationship between the dividend policy, agency cost, and bank performance having MR as the intervening variable. More so, the fact that no known study has examined this relationship piqued the interest for this study using the selected SSA countries, a new data set. This is considered necessary at this time because a firm's major long-term goal is to deal with market or systematic risk.

\section{Theoretical framework: modern portfolio theory}

This theory focuses on rational investors' ability to assess and obtain an optimal trade-off between the risks and returns embedded in their investments so as to build a sound portfolio. It shows how a risk-averse shareholder can construct a portfolio and maximise the expected part of returns in any firm. It shows that a sound portfolio will maximise returns with a given level of risk or minimise risk for a given amount of returns derivable from the combination of various assets. In terms of this theory, the impact of unsystematic risk emanating from external contingencies in each market is reduced through the allocation of assets across diverse markets. Thus, diversification reduces a firm's exposure to risk and it also enjoys higher debt and leverage capacity which create room for expansion and growth (Karkowska, 2019). 


\section{Research method}

\subsection{Research design}

Using proportionate stratified simple random sampling techniques, annual data were collected from 250 commercial banks' financial profile with up-to-date data available in the BankScope database by Fitch/ IBCA Bureau Van Dijk covering the period 2008 to 2017. The SSA countries considered in this study exclude those regarded as outliers such as South Africa and Mauritius due their highly competitive and sophisticated banking systems (Beck, Cull, 2013). Countries such as such as the Democratic Republic of Congo, Comoros, GuineaBissau, Sao Tome and Principle and that lacked data due to the effects of war were also excluded (Akande, Kwenda, 2017; Flamini, Schumacher, McDonald, 2009). The countries selected are bank-based economies in which commercial banking holds more than $70 \%$ of financial system assets on average. The macro-economic variables used in this study are sourced from the World Development Indicators (WDI) and International Financial Statistics (IFS).

\subsection{Model Specification}

The portfolio theory is used to evaluate the relationship between these variables. It posits that investors are risk averse and prefer managers to construct their portfolio to maximise returns with provision made for a given level of MR such that risk is treated as an integral component of returns. Banks' profitability is affected by management policies (investment, financing and dividend), location, size and risk, either market or unsystematic risk (Haslem, 1968).

$$
\text { Hence, Profitability }=\mathrm{f}(\text { dividend policy, agency cost and MR) }
$$

The following studies were followed to choose proxies for the variables: Agency cost - Ang, Cole, and Lin (2000); Singh and Davidson III (2003); Gul, Sajid, Razzaq, and Afzal (2012); Nazir, Saita, and Nawaz (2012); Dividend policy - Ling, Abdull Mutalip, Shahrin, and Othman (2007); Ouma (2012) and Hamid, Yaqub, and Awan (2016) and MR - Feldman and Schmidt (2000); Kasman and Carvallo (2013) and Ekinci (2016).

Performance $=\mathrm{f}($ Dividend payout ratio, Asset utilisation ratio, Lending Interest rate and Exchange rate)

$$
\begin{gathered}
R O A=\mathrm{f}(D P O R, A U R, L I R, F E X R) \\
R O A_{i t}=\beta_{0}+\beta_{1} D P O R_{i t}+\beta_{2} A U R_{i t}-\beta_{3} L I R_{i t}+\beta_{4} \ln F E X R_{i t}+\varepsilon_{i t}
\end{gathered}
$$


Only exchange rate is in natural logarithm form while the others are in their natural or ratio form.

$\left[\begin{array}{c}\Delta R O A_{i t} \\ \Delta D P O R_{i t} \\ \Delta A U R_{i t} \\ \Delta L I R_{i t} \\ \Delta \ln F E X R_{i t}\end{array}\right]=\left[\begin{array}{c}\theta_{0} \\ \beta_{0} \\ \alpha_{0} \\ \delta_{0} \\ \psi_{0}\end{array}\right]+\sum_{k=1}^{p}\left[\begin{array}{ccccc}\theta_{1 i} & \theta_{2 i} & \theta_{3 i} & \theta_{4 i} & \theta_{5 i} \\ \beta_{1 i} & \beta_{2 i} & \beta_{3 i} & \beta_{4 i} & \beta_{5 i} \\ \alpha_{1 i} & \alpha_{2 i} & \alpha_{3 i} & \alpha_{4 i} & \alpha_{5 i} \\ \delta_{1 i} & \delta_{2 i} & \delta_{3 i} & \delta_{4 i} & \delta_{5 i} \\ \psi_{1 i} & \psi_{2 i} & \psi_{3 i} & \psi_{4 i} & \psi_{5 i}\end{array}\right]\left[\begin{array}{c}\Delta R O A_{i(t-k)} \\ \Delta D P O R_{i(t-k)} \\ \Delta A U R_{i(t-k)} \\ \Delta L I R_{i(t-k)} \\ \Delta \ln F E X R_{i(t-k)}\end{array}\right]+\left[\begin{array}{c}\theta_{6} \\ \beta_{6} \\ \alpha_{6} \\ \delta_{6} \\ \psi_{6}\end{array}\right] E_{t-1}+\left[\begin{array}{c}\varepsilon_{1 i t} \\ \varepsilon_{2 i t} \\ \varepsilon_{3 i t} \\ \varepsilon_{4 i t} \\ \varepsilon_{5 i t}\end{array}\right]$

$\theta_{0}, \beta_{0}, \alpha_{0}, \delta_{0}, \psi_{0}$ are respective constants,

$\theta_{1}-\theta_{6}, \beta_{1}-\beta_{6}, \alpha_{1}-\alpha_{6}, \delta_{1}-\delta_{6}, \psi_{1}-\psi_{6}$ are respective estimated coefficients.

$\Delta$ denotes the first difference operator. $E C T_{t-1}$ represents the one-year lagged Error Correction Term. It is the co-integrating vector that acts as the speed of adjustment for the long run association between the variables. $\varepsilon_{1 i t}-\varepsilon_{5 i t}$ are mutually uncorrelated stochastic (white noise) error terms with a finite covariance matrix and zero mean value. $t$ is the time-period (years) that ranges from $1,2, \ldots, 10, i$ is the cross-section (banks) that ranges from $1,2, \ldots$, 250 and lastly, $k$ is the number of lags while $p$ is the optimal lag length selected by using the Sequential modified LR test statistic, Final Prediction Error, Akaike Information Criterion (AIC), Schwarz Bayesian criterion (SBC) and Hannan-Quinn information criterion.

\subsection{Estimating Technique}

The Panel Vector Error Correction Model, Impulse Response and Variable Decomposition techniques were used to evaluate the dynamic relationship between the variables in model 3 . VECM adds error correction features to a multi factor vector auto regression. It is suitable when the study variables have a long run stochastic trend (co-integrated). The error correction shows that the past year deviation from long run equilibrium, that is, the error, influences its short run dynamics. Hence, the speed at which the dependent variable (a bank's ROA) returns to equilibrium after a change in other variables was estimated directly by Error Correction Models. ECM methodology was developed by Sargan (1964) while VECM was fully analysed by Johansen (1995) to ensure that the long run adjustment of the co-integrated series is properly accounted for.

The Panel-VEC model is:

If $Y_{i t}=\left(Y_{1 i t}, Y_{2 i t}, Y_{3 i t}, \ldots, Y_{\text {qit }}\right)^{\prime}$ is a $q \times 1$ vector of cross-sections $i$ in time $t$ 


$$
Y_{i t}=\delta_{i} b_{t}+\sum_{k=1}^{m} \Phi_{i k} Y_{i(t-k)}+\varepsilon_{i t}
$$

where:

$t=1,2,3, \ldots, T ; i=1,2,3, \ldots, N ; \Phi_{i k}$ is a $q \times q$ matrix;

$\varepsilon_{i t}$ is the $q \times 1$ vector of disturbances; and $b_{t}$ which is a vector of deterministic components is equal to 1 .

That is, $\delta_{i}$ is a $q \times 1$ or $q \times 2$ matrix of parameters.

Therefore, $\delta_{i} b_{t}$ is a $q \times 1$ vector with the $k$-th element which is equal to $\delta_{1 i k}$ or $\delta_{1 i k}+\delta_{2 i k}+$ $\ldots+t$ denoting the model's deterministic component.

$$
\text { Explicitly, } \Delta Y_{i t}=\delta_{i} b_{t}+\Pi_{i} Y_{i(t-1)}+\sum_{k=1}^{m-1} \Gamma_{i k} \Delta Y_{i(t-k)}+\varepsilon_{i t}
$$

where:

$$
\begin{aligned}
& t=1,2,3, \ldots, t ; i=1,2,3, \ldots, N ; \Gamma_{i k}=-\sum_{w=k+1}^{m} \Phi_{i w} \text { for } k=1,2,3, \ldots,(m-1) \text { and, } \\
& \Pi_{i}=-\left(\mathrm{I}_{j}-\sum_{k=1}^{m} \Phi_{i k}\right) . \text { Moreover, } \Gamma_{i}=\left(\Gamma_{1 i}, \Gamma_{2 i}, \Gamma_{3 i}, \ldots, \Gamma_{i(m-1)}\right) \\
& \text { and } X_{i t}=\left(\Delta Y_{i(t-1)^{\prime}}, \Delta Y_{i(t-2)}, \Delta Y_{i(t-3)}, \ldots, \Delta Y_{i, t-(m-1)^{\prime}}\right)^{\prime} .
\end{aligned}
$$

Equation 5 can be re-written as:

$$
\Delta Y_{i t}=\delta_{i} b_{t}+\prod_{i} Y_{i(t-1)}+\Gamma_{i} X_{i t}+\varepsilon_{i t}
$$

For a given time-period $t$, model 6 can be stacked over the cross-section $i$ to obtain;

$$
\Delta Y_{t}=\delta b_{t}+\Pi Y_{t-1}+\Gamma X_{t}+\varepsilon_{t}
$$

For every $t$ ranges from $t=1,2,3, \ldots, T$.

In the same manner, equation (7) can be expressed in a matrix form as:

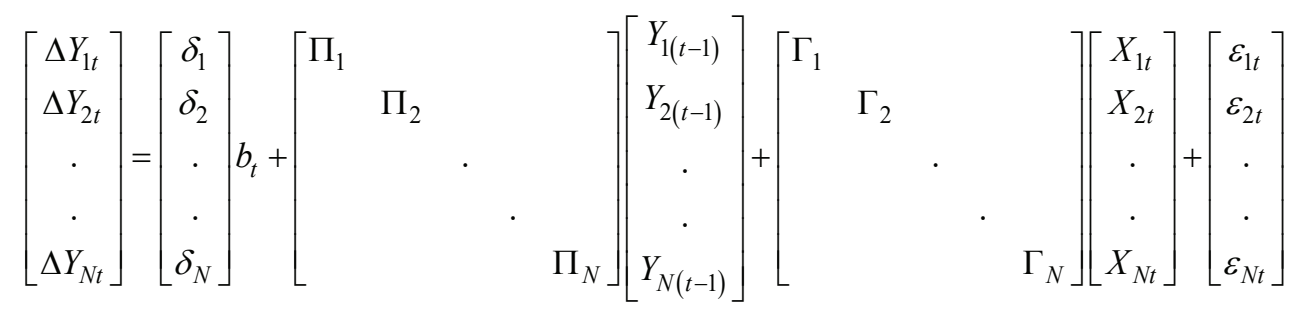


Equation 6 is the usual VEC model.

Thus, it is assumed that $\varepsilon_{i t}$ is I.I.D with a mean value equal to zero and co variance matrix denoted as:

$$
\Omega=\left[\begin{array}{cccc}
\Omega_{11} & \cdot & \cdot & \Omega_{1 N} \\
\cdot & \cdot & & \\
\cdot & & \cdot & \\
\Omega_{N 1} & \cdot & \cdot & \Omega_{N N}
\end{array}\right] .
$$

This is $N_{q} \times N_{q}$ positive definite matrix such that $\Omega_{i k} \equiv \operatorname{var}\left(\varepsilon_{i t}\right)$. Following the study of Groen and Kleibergen (2003),

If $\Pi_{i}$ is decomposed into $\alpha_{i} \beta_{i}^{\prime}$ where, $\alpha_{i}$ and $\beta_{i}$ are of dimension $q \times r_{i}$ with $r_{i}$ equal to rank $\left(\Pi_{i}\right)<q$. This denotes that the cointegration rank varies across cross-sections, which is in tandem with the existing literature on panel cointegration that posits that individual crosssections usually have the same cointegration rank; that is $r_{i}=r$ for all $i$. When $\Pi=\alpha \beta^{\prime}$, then the long run coefficient matrix $\Pi$ is;

$$
\alpha=\left[\begin{array}{lllll}
\alpha_{1} & & & & \\
& \alpha_{2} & & & \\
& & \cdot & & \\
& & & \cdot & \\
& & & \alpha_{N}
\end{array}\right], \beta=\left[\begin{array}{lllll}
\beta_{1} & & & \\
& \beta_{2} & & \\
& & \cdot & \\
& & & \cdot & \\
& & & \beta_{N}
\end{array}\right] .
$$

Conclusively, a panel-VEC model is written as

$$
\Delta Y_{i t}=\delta b_{i t}+\alpha \beta^{\prime} Y_{i(t-1)}+\Gamma X_{i t}+\varepsilon_{i t}
$$

From equation 8 , the short run matrix, $\Gamma$; adjustment matrix, $\alpha$ and the cointegration matrix, $\beta$ are expressed below respectively.

$$
\Gamma=\left[\begin{array}{cccccc}
\Gamma_{11} & \Gamma_{12} & \cdot & \cdot & \cdot & \Gamma_{1 N} \\
\Gamma_{21} & \Gamma_{22} & \cdot & \cdot & \cdot & \Gamma_{2 N} \\
\cdot & \cdot & \cdot & & & \cdot \\
\cdot & \cdot & & \cdot & & \cdot \\
\cdot & \cdot & & & \cdot & \cdot \\
\Gamma_{N 1} & \Gamma_{N 2} & . & . & . & \Gamma_{N N}
\end{array}\right], \alpha=\left[\begin{array}{cccccc}
\alpha_{11} & \alpha_{12} & \cdot & \cdot & \cdot & \alpha_{1 N} \\
\alpha_{21} & \alpha_{22} & \cdot & \cdot & \cdot & \alpha_{2 N} \\
\cdot & \cdot & \cdot & & \cdot \\
\cdot & \cdot & & \cdot & \cdot \\
\cdot & \cdot & & & \cdot \\
\alpha_{N 1} & \alpha_{N 2} & \cdot & \cdot & \cdot & \alpha_{N N}
\end{array}\right]
$$


and

$$
\beta=\left[\begin{array}{cccccc}
\beta_{11} & \beta_{12} & \cdot & \cdot & \cdot & \beta_{1 N} \\
\beta_{21} & \beta_{22} & \cdot & \cdot & \cdot & \beta_{2 N} \\
\cdot & \cdot & \cdot & & & \cdot \\
\cdot & \cdot & & \cdot & & \cdot \\
\cdot & \cdot & & & \cdot & \cdot \\
\beta_{N 1} & \beta_{N 2} & \cdot & \cdot & \cdot & \beta_{N N}
\end{array}\right] .
$$

The unrestricted matrices of $\alpha$ and $\beta$ are of the dimension $N q \times r$, where, $r \equiv r_{1}+r_{2}+\ldots+r_{N}<N q$.

Therefore, after this model has been estimated, the impulse response and variable composition is analysed to show the dynamic behaviour of a variable due to a random shock in other variables. Thus, for each variable from each equation, a unit shock to the error is analysed to determine the effects upon the vector error correction mechanism system over time using the Cholesky decomposition.

\subsection{Variable Definition}

Dividend Payout Ratio (DPOR). This variable is used to capture the dividend payout policy. In the context of this study, we treat payout as the cash dividend payout and not stock dividend or stock repurchase. It shows the proportion of a bank's income distributed to shareholders in the form of cash. It is measured as: $\frac{\text { Total dividend }}{\text { Total earnings }} \cdot 100$.

This variable was used by Agyei and Marfo-Yiadom (2011), Nnadi, Wogboroma, and Kabel (2013), Agyemang Badu (2013) and Maldajian and El Khoury (2014) because it shows the proportion of dividend paid out.

Return on Assets (ROA). This measure of performance indicates how profitable a bank is with respect to its total assets. This ratio points to how bank management is at using its total assets component to generate earnings. It was calculated as $\frac{\text { Profit after tax }}{\text { Total asset }} \cdot 100$.

The ratio has been used by various scholars to measure performance, including Ouma (2012), Agyei and Marfo-Yiadom (2011), Onanjiri and Korankye (2014) and Ehikioya (2015).

Asset Utilisation Ratio (AUR). This ratio was used to proxy the agency costs of banks following the work of Ang et al. (2000), Gul et al. (2012) and Nazir et al. (2012). It was captured as: $\frac{\text { Total income }}{\text { Total asset }} \cdot 100$. 
Lending Interest Rate (LIR). This was used as a measure of MR in this study in line with Kasman and Carvallo (2013) and Ekinci (2016). It was extracted from the WDI.

Real Exchange Rate (FEXR). This was used as a measure of MR in this study following Ekinci (2016). It was extracted from the WDI and was naturally logged in this study as it is the ratio of the local currency of each country to the US Dollar.

\section{Result of Data Estimation}

\subsection{Panel Unit Root}

Secondary data is used in this study; however, before analysing this data, the stationary test must be conducted so as to detect the order of integration in case there is a co-integrating relationship between the variables so avoiding a spurious analysis. The empirical findings affirmed that none of the various unit root tests is free from power properties and size shortcomings; hence, to ensure authentic evidence on the order of integration, several unit root tests such as Levin, Lin, and Chu (2002); Choi (2001) ADF Chi Square; and the Maddala and $\mathrm{Wu}(1999)$ Fisher type panel unit root tests were conducted.

Table 1. Levin Lin and Chu (LLC), Im, Pesaran and Chin, Augmented the Dickey Fuller (ADF) and Maddala and Wu (PP) Fisher-type Unit Root Tests

\begin{tabular}{|c|c|c|c|c|c|}
\hline Variables & Order & $t^{*}$ Stat & Prob-Value & $\mathrm{t}^{*}$ Stat & Prob-Value \\
\hline 1 & 2 & 3 & 4 & 5 & 6 \\
\hline & & \multicolumn{2}{|c|}{ Levin, Lin, and Chu (None) } & \multicolumn{2}{|c|}{ Levin, Lin, and Chu (Individual Intercept) } \\
\hline ROA & I (1) & -48.665 & $0.000 * * *$ & -36.650 & $0.000 * * *$ \\
\hline DPOR & I (1) & -46.745 & $0.000 * * *$ & -11.248 & $0.000 * * *$ \\
\hline AUR & I (1) & -31.391 & $0.000 * * *$ & -17.147 & $0.000 * * *$ \\
\hline LIR & I (1) & -191.822 & $0.000 * * *$ & -185.195 & $0.000 * * *$ \\
\hline \multirow[t]{2}{*}{ FEXR } & I (1) & -6.293 & $0.000 * * *$ & -55.835 & $0.000 * * *$ \\
\hline & & \multicolumn{2}{|c|}{ Im, Pesaran and Chin (None) } & \multicolumn{2}{|c|}{ Im, Pesaran and Chin (Individual intercept) } \\
\hline ROA & I (1) & N/A & N/A & -13.443 & $0.000 * * *$ \\
\hline DPOR & I (1) & N/A & N/A & -14.946 & $0.000 * * *$ \\
\hline AUR & I (1) & N/A & N/A & -6.2326 & $0.000 * * *$ \\
\hline LIR & I (1) & N/A & N/A & -39.855 & $0.000 * * *$ \\
\hline FEXR & I (1) & N/A & N/A & -25.012 & $0.000 * * *$ \\
\hline
\end{tabular}




\begin{tabular}{|c|c|c|c|c|c|}
\hline 1 & 2 & 3 & 4 & 5 & 6 \\
\hline & & \multicolumn{2}{|c|}{$\begin{array}{l}\text { ADF Fisher Chi-square Unit-root test } \\
\text { (None) }\end{array}$} & \multicolumn{2}{|c|}{$\begin{array}{l}\text { ADF Fisher Chi-square Unit-root test } \\
\text { (Individual intercept) }\end{array}$} \\
\hline ROA & I (1) & 1960.44 & $0.000 * * *$ & 1061.55 & $0.000 * * *$ \\
\hline DPOR & I (1) & 2093.19 & $0.000 * * *$ & 1142.17 & $0.000^{* * *}$ \\
\hline AUR & I (1) & 913.316 & $0.000 * * *$ & 410.733 & $0.000 * * *$ \\
\hline LIR & I (1) & 1422.29 & $0.000 * * *$ & 958.485 & $0.000 * * *$ \\
\hline \multirow[t]{2}{*}{ FEXR } & I (1) & 520.324 & $0.000 * * *$ & 333.150 & $0.000 * * *$ \\
\hline & & \multicolumn{2}{|c|}{$\begin{array}{l}\text { PP Fisher-type Chi Square Unit root-test } \\
\text { (None) }\end{array}$} & \multicolumn{2}{|c|}{$\begin{array}{l}\text { PP Fisher-type Chi Square Unit root-test } \\
\text { (Individual intercept) }\end{array}$} \\
\hline ROA & I (1) & 3188.80 & $0.000 * * *$ & 2352.11 & $0.000 * * *$ \\
\hline DPOR & I (1) & 3376.91 & $0.000 * * *$ & 2417.23 & $0.000 * * *$ \\
\hline AUR & I (1) & 1555.13 & $0.000 * * *$ & 917.255 & $0.000 * * *$ \\
\hline LIR & I (1) & 1458.73 & $0.000 * * *$ & 980.303 & $0.000 * * *$ \\
\hline FEXR & I (1) & 1815.24 & $0.000 * * *$ & 1756.79 & $0.000 * * *$ \\
\hline
\end{tabular}

Note that $* * *$ represents $1 \%$ level of significance.

Source: author's estimation (2020).

The panel unit root test presented in the table above shows that all the variables were stationary at first differencing (order one). Return on assets, the dividend payout ratio, asset utilisation ratio, lending interest rate and foreign exchange rate were all stationary at order one (I (1)) at both cross section and individual level during the study period. The reason is that the probability of the Levin, Lin and Chin; Im, Pesaran and Chin t-statistic values: 0.000, 0.000, 0.000 and 0.000; Augmented Dickey Fuller (ADF) test statistic and Philip Perron statistic values: $0.000,0.000,0.000$ and 0.000 for each variable was less than the probability of the error margin 0.05 allowed for in the estimate in this study. This result implies that there is a short run equilibrium relationship between the variables under investigation. The short run stability of these variables as revealed by the panel unit root test led to further description of the variables, the level of correlation between them and estimation of cointegration to determine the long run equilibrium relationship or stability of the linear combination of the variables in the long run.

\subsection{Vector Auto-Regression Optimal Lag Selection}

Different criteria are used to choose the optimal lag structure for the model. According to Hyndman and Athanasopoulos (2014), AIC criteria tend to choose a larger number of lags, hence, for VAR and VEC analysis, SIC is preferable (Obalade, Ebiwonjumi, Adaramola, 2019). 
Table 2. Optimal Lag Selection of Series: ROA, DPOR, AUR, LIR and FEXR

\begin{tabular}{|c|c|c|c|c|c|c|}
\hline LAG & LOGL & LR & FPE & AIC & SIC & HQIC \\
\hline 0 & -2055.709 & NA & 0.126 & 12.121 & 12.178 & 12.178 \\
\hline 1 & -539.949 & 2978.022 & $1.97 \mathrm{e}-05$ & 3.352 & 3.690 & 3.690 \\
\hline 2 & -427.053 & 218.486 & $1.17 \mathrm{e}-05$ & 2.835 & $3.454^{*}$ & $3.454^{*}$ \\
\hline 3 & -405.690 & 40.715 & $1.20 \mathrm{e}-05$ & 2.857 & 3.757 & 3.757 \\
\hline 4 & -374.972 & 57.641 & $1.16 \mathrm{e}-05^{*}$ & $2.823 *$ & 4.005 & 4.005 \\
\hline 5 & -359.676 & 28.251 & $1.23 \mathrm{e}-05$ & 2.880 & 4.344 & 4.344 \\
\hline 6 & -327.485 & $58.511^{*}$ & $1.18 \mathrm{e}-05$ & 2.838 & 4.583 & 4.583 \\
\hline
\end{tabular}

Note that $(*)$ indicates the lag order selected by each criterion; LR: Sequential modified LR test statistic (each at 5\% level of significance); FPE: Final Prediction Error; AIC: Akaike Information Criterion; SIC: Schwarz information criterion; HQIC: Hannan-Quinn information criterion.

Source: author's estimation (2020).

Table 2 shows the result of the Vector Auto Regression lag length criteria to select the most appropriate lag for this study. The VECM model of lag order of four (4) is revealed using the Akaike information and Final Prediction Error criterion with values of 2.823 and $1.16 \mathrm{e}-05^{*}$, respectively, the sequential modified LR test statistic selects lag 6 with a value 58.511, and the VECM of lag order of two (2) is revealed using the Schwarz information criterion and Hannan-Quinn information criterion with the same values given as 3.454. All these information criteria are statistically significant at the 5 percent level. Based on this evidence, a VECM of lag order two (2) which is the smallest lag order revealed by the Schwarz information criterion and Hannan-Quinn information criterion, is selected for this study.

\subsection{Panel Cointegration Test}

According to Abadir and Taylor (1999), the cointegration test is conducted to test for significant deviation of the integrated variables from a certain relationship. Cointegration means the presence of a long-run association between economic variables such that co-integrated variables enable the correction of short-term disturbances in the long-term. From the evidence of the unit root test that the variables are integrated at the same order I (1), there is a need to test for the existence of a long run association between the variables. Therefore, the Kao ADF Residual based test is used to test the long run co-movement of these series. 
Table 3. Kao ADF Residual Based Cointegration Test of Series: ROA, DPOR, AUR, LIR, and FEXR

\begin{tabular}{|c|c|c|}
\hline \multicolumn{3}{|c|}{ Ho: There is No Cointegration } \\
\hline \multicolumn{3}{|c|}{ Trend Assumption: No deterministic Trend } \\
\hline ADF & t-Statistic & Prob. Value \\
\hline
\end{tabular}

Note that $* * *$ represents a rejection of the null hypothesis at a $5 \%$ level of significance.

Source: author's estimation (2020).

The estimate from the Kao Residual ADF test in the table above was significant at 5 percent with the t-statistics -3.154 ; hence, the null hypothesis is rejected and there is confirmed evidence that the variables are co-integrated in the long run.

\subsection{Vector Error Correction Estimations}

According to Mahadevan and Asafu-Adjaye (2007), the two common methods of detecting the direction of causality between co-integrated variables are VAR and VECM; hence, VECM is used in this study to show the long run relationship between the variables based on affirmation of the long run association between the variables. The VECM with five (5) simultaneous equations is estimated to examine the short run properties of the long run relationships between the study series. A VECM is a restricted VAR used for a non-stationary co-integrated series. VEC is of more merit than VAR because its cointegration relations are built in its specification such that the endogenous variables' long-run behaviour is restricted to cause convergence in the co-integrating relationships, allowing for short-run adjustment dynamics in the series. The cointegration term built in the VECM is called the error correction term since any deviation from the long-run equilibrium is expected to be corrected with a gradual speed of short-run adjustment. Following the studies of Asari et al. (2011) and Hyndman and Athanasopoulos (2014), SIC is also used as a criterion to choose optimal lag two (2) in this study as AIC tends to choose a larger number of lags that can render the VEC estimate insignificant.

Table 4. Vector Error Correction Estimates

\begin{tabular}{|l|c|c|c|c|c|}
\hline \multicolumn{1}{|c|}{ Co-integrating Eq } & CointEq1 & CointEq2 & CointEq3 & CointEq4 & \\
\hline \multicolumn{1}{|c|}{1} & 2 & 3 & 4 & 5 & 6 \\
\hline ROA $(-1)$ & 1.000 & 0.000 & 0.000 & & \\
\hline DPOR $(-1)$ & 0.000 & 1.000 & 0.000 & & \\
\hline LIR $(-1)$ & 0.000 & 0.000 & 1.000 & & \\
\hline
\end{tabular}




\begin{tabular}{|c|c|c|c|c|c|}
\hline 1 & 2 & 3 & 4 & 5 & 6 \\
\hline $\operatorname{FEXR}(-1)$ & 0.000 & 0.000 & 0.000 & 1.000 & \\
\hline $\operatorname{AUR}(-1)$ & $\begin{array}{c}0.004 \\
(0.000) \\
\end{array}$ & $\begin{array}{l}-0.049 \\
(0.007)\end{array}$ & $\begin{array}{l}29.152 \\
(2.375)\end{array}$ & $\begin{array}{c}6.751 \\
(0.533) \\
\end{array}$ & \\
\hline $\mathrm{C} 1$ & -0.032 & -0.359 & -79.115 & -18.713 & \\
\hline Error Correction: & $\triangle R O A$ & $\triangle D P O R$ & $\Delta L I R$ & $\triangle F E X R$ & $\triangle A U R$ \\
\hline CointEq1 & $\begin{array}{l}-0.359 \\
(0.029)\end{array}$ & $\begin{array}{l}-0.010 \\
(0.218)\end{array}$ & $\begin{array}{l}-1.220 \\
(4.167) \\
\end{array}$ & $\begin{array}{l}-0.095 \\
(0.127)\end{array}$ & $\begin{array}{l}-2.946 \\
(4.319) \\
\end{array}$ \\
\hline CointEq2 & $\begin{array}{l}-0.008 \\
(0.004)\end{array}$ & $\begin{array}{l}-0.288 \\
(0.035)\end{array}$ & $\begin{array}{l}-1.257 \\
(0.673)\end{array}$ & $\begin{array}{l}-0.001 \\
(0.020)\end{array}$ & $\begin{array}{l}-0.789 \\
(0.697)\end{array}$ \\
\hline CointEq3 & $\begin{array}{l}-3.25 \mathrm{E}-05 \\
(9.5 \mathrm{E}-05)\end{array}$ & $\begin{array}{c}-1.21 \mathrm{E}-05 \\
(0.000)\end{array}$ & $\begin{array}{l}-0.052 \\
(0.013)\end{array}$ & $\begin{array}{l}-0.000 \\
(0.000)\end{array}$ & $\begin{array}{l}-0.006 \\
(0.013)\end{array}$ \\
\hline CointEq4 & $\begin{array}{c}-2.41 \mathrm{E}-05 \\
(0.000)\end{array}$ & $\begin{array}{c}-0.002 \\
(0.003) \\
\end{array}$ & $\begin{array}{c}0.232 \\
(0.057) \\
\end{array}$ & $\begin{array}{l}-0.003 \\
(0.001) \\
\end{array}$ & $\begin{array}{r}-0.095 \\
(0.059) \\
\end{array}$ \\
\hline$\triangle R O A_{(-1)}$ & $\begin{array}{l}-0.215 \\
(0.033) \\
\end{array}$ & $\begin{array}{l}-0.002 \\
(0.245) \\
\end{array}$ & $\begin{array}{l}-11.211 \\
(4.687) \\
\end{array}$ & $\begin{array}{l}-0.224 \\
(0.143) \\
\end{array}$ & $\begin{array}{c}0.243 \\
(4.858) \\
\end{array}$ \\
\hline$\Delta R O A_{(-2)}$ & $\begin{array}{l}-0.023 \\
(0.025)\end{array}$ & $\begin{array}{c}0.057 \\
(0.189)\end{array}$ & $\begin{array}{l}-10.919 \\
(3.615) \\
\end{array}$ & $\begin{array}{l}-0.251 \\
(0.110)\end{array}$ & $\begin{array}{c}0.003 \\
(3.747)\end{array}$ \\
\hline$\triangle D P O R_{(-1)}$ & $\begin{array}{c}0.003 \\
(0.005) \\
\end{array}$ & $\begin{array}{l}-0.277 \\
(0.039) \\
\end{array}$ & $\begin{array}{c}1.192 \\
(0.745) \\
\end{array}$ & $\begin{array}{c}0.017 \\
(0.022) \\
\end{array}$ & $\begin{array}{c}1.656 \\
(0.772) \\
\end{array}$ \\
\hline$\triangle D P O R_{(-2)}$ & $\begin{array}{l}-0.002 \\
(0.004)\end{array}$ & $\begin{array}{l}-0.069 \\
(0.032)\end{array}$ & $\begin{array}{l}-0.632 \\
(0.622)\end{array}$ & $\begin{array}{l}-0.008 \\
(0.019)\end{array}$ & $\begin{array}{l}-0.268 \\
(0.645)\end{array}$ \\
\hline$\Delta L I R_{(-1)}$ & $\begin{array}{l}-0.000 \\
(0.000)\end{array}$ & $\begin{array}{c}0.004 \\
(0.001) \\
\end{array}$ & $\begin{array}{c}0.200 \\
(0.036) \\
\end{array}$ & $\begin{array}{l}-0.002 \\
(0.001) \\
\end{array}$ & $\begin{array}{l}-0.037 \\
(0.037) \\
\end{array}$ \\
\hline$\Delta L I R_{(-2)}$ & $\begin{array}{l}-0.000 \\
(0.000)\end{array}$ & $\begin{array}{l}-0.004 \\
(0.001)\end{array}$ & $\begin{array}{l}-0.035 \\
(0.030)\end{array}$ & $\begin{array}{c}0.000 \\
(0.000)\end{array}$ & $\begin{array}{c}0.003 \\
(0.031)\end{array}$ \\
\hline$\Delta F E X R_{(-1)}$ & $\begin{array}{c}0.010 \\
(0.010)\end{array}$ & $\begin{array}{l}-0.021 \\
(0.073)\end{array}$ & $\begin{array}{l}11.596 \\
(1.405)\end{array}$ & $\begin{array}{c}0.154 \\
(0.042)\end{array}$ & $\begin{array}{l}-0.347 \\
(1.456)\end{array}$ \\
\hline$\Delta F E X R_{(-2)}$ & $\begin{array}{c}0.001 \\
(0.009) \\
\end{array}$ & $\begin{array}{c}0.082 \\
(0.068) \\
\end{array}$ & $\begin{array}{l}-5.157 \\
(1.314) \\
\end{array}$ & $\begin{array}{c}0.054 \\
(0.040) \\
\end{array}$ & $\begin{array}{c}2.775 \\
(1.362) \\
\end{array}$ \\
\hline$\Delta A U R_{(-1)}$ & $\begin{array}{c}0.000 \\
(0.000)\end{array}$ & $\begin{array}{c}6.63 \mathrm{E}-05 \\
(0.001) \\
\end{array}$ & $\begin{array}{l}-0.052 \\
(0.036) \\
\end{array}$ & $\begin{array}{l}-0.003 \\
(0.001) \\
\end{array}$ & $\begin{array}{l}-0.274 \\
(0.038) \\
\end{array}$ \\
\hline$\Delta A U R_{(-2)}$ & $\begin{array}{c}0.000 \\
(0.000)\end{array}$ & $\begin{array}{c}0.001 \\
(0.001) \\
\end{array}$ & $\begin{array}{l}-0.050 \\
(0.031) \\
\end{array}$ & $\begin{array}{l}-0.002 \\
(0.000) \\
\end{array}$ & $\begin{array}{l}-0.145 \\
(0.032) \\
\end{array}$ \\
\hline $\mathrm{C} 2$ & $\begin{array}{l}-0.001 \\
(0.001)\end{array}$ & $\begin{array}{l}-0.003 \\
(0.007) \\
\end{array}$ & $\begin{array}{l}-0.528 \\
(0.152) \\
\end{array}$ & $\begin{array}{c}0.051 \\
(0.004) \\
\end{array}$ & $\begin{array}{l}-0.260 \\
(0.157) \\
\end{array}$ \\
\hline R-squared & 0.314 & 0.286 & 0.235 & 0.062 & 0.413 \\
\hline Adj. R-squared & 0.301 & 0.272 & 0.220 & 0.044 & 0.401 \\
\hline Sum sq. Resids & 0.390 & 21.060 & 7688.658 & 7.199 & 8260.288 \\
\hline S.E. equation & 0.0232 & 0.170 & 3.263 & 0.099 & 3.382 \\
\hline F-statistic & 23.655 & 20.697 & 15.894 & 3.443 & 36.309 \\
\hline Log likelihood & 1733.570 & 264.322 & -1909.858 & 659.883 & -1936.285 \\
\hline Akaike AIC & -4.663 & -0.676 & 5.223 & -1.750 & 5.295 \\
\hline Schwarz SC & -4.570 & -0.582 & 5.317 & -1.656 & 5.388 \\
\hline Mean dependent & -0.000 & -0.002 & -0.152 & 0.062 & -0.159 \\
\hline S.D. dependent & 0.027 & 0.200 & 3.696 & 0.102 & 4.373 \\
\hline
\end{tabular}

Note that standard errors (SE) are in parenthesis.

Source: author's estimation (2020). 
The presence of cointegration between variables suggests a long-term relationship between the variables under consideration. The VECM can then be applied. The vector error correction estimate with standard error in parenthesis for the long run relationship between dividend policy and banking performance for three co-integrating equations is presented in the table above. To establish a long-run relationship, the ECT, that is, the coefficients should be negative and statistically significant. A negative and significant ECT coefficient indicates that any short-term fluctuations between the regressors and the dependent variable will result in a stable long run relationship between the variables. The ECTs $\left(\mathrm{ECT}_{t-1}\right)$ are correctly signed and significant for the four (4) co-integrating equations except LIR in COINTEQ4. Furthermore, the C1 in the co-integrating equation is also correctly signed and it reveals that it will take $0.033,0.359$, 79.116 and 18.713 percent, respectively for the maladjustment in co-integrating equations 1 , 2 and 3 to adjust to the long run equilibrium or stability. In examining the impact of the error correction of dividend policy, agency costs and MR on bank performance, it was found from the fitted vector error correction mechanism that $\mathrm{ROA}_{(-1)}, \mathrm{ROA}_{(-2)}$ and $\mathrm{CAR}_{(-1)}$ have an inverse relationship with ROA. Thus, $\mathrm{ROA}_{(-1)}, \mathrm{ROA}_{(-2)}, \mathrm{DPOR}_{(-2)}, \mathrm{LIR}_{(-1)}, \mathrm{LIR}_{(-2)}$ and $\mathrm{AUR}_{(-2)}$ will worsen the performance of the banking industry by $21.527,0.235,0.217,0.024,0.021$ and 0.022 percent, respectively. However, $\mathrm{DPOR}_{(-1)} ; \mathrm{FEXR}_{(-1)} ; \mathrm{FEXR}_{(-2)}, \mathrm{AUR}_{(-1)}$ and $\mathrm{AUR}_{(-2)}$ have a direct relationship with ROA at $0.385 ; 1.022 ; 0.125$ and 0.022 percent, respectively. The positive relationship of FEXR which is one of the proxies of MR conforms to the a priori expectation and Ekinci (2016), while the negative relationship of LIR with ROA conforms to the a priori expectation, Kasman and Carvallo (2013) and Ekinci (2016). In the same vein, the finding on DPOR is in tandem with the a priori expectation and the empirical findings of Agyei and Marfo-Yiadom (2011); Uwuigbe, Jafaru, and Ajayi (2012); Ajanthan (2013) and Ehikioya (2015), while the mixed findings on agency costs are in tandem with Wang (2010) and Alencar and Nakane (2004). The results further reveal that $\mathrm{ROA}_{(-1)}, \mathrm{DPOR}_{(-1)}, \mathrm{DPOR}_{(-2)}$, $\operatorname{LIR}_{(-2)}$ and FEXR $(-1)$ have negative relationships with DPOR to the tune of $0.0240 ; 27.776$; 6.959; 0.044 and 2.15 percent, while $\mathrm{ROA}_{(-2)} ; \mathrm{LIR}_{(-1)} ; \mathrm{FEXR}_{(-2)}, \mathrm{AUR}_{(-1)}$ and $\mathrm{AUR}_{(-2)}$ posit positive relationships with DPOR at $5.701 ; 0.040 ; 8.223 ; 0.000$ and 0.013 percent, respectively.

From the perspective of LIR and FEXR, DPOR (-1) depicts a positive relationship with MR, that is, LIR and FEXR at 111.92 and 1.7911 percent, respectively; LIR (-1) shows a 20.07 percent positive relationship with LIR and LIR (-2) illustrates a 0.0189 percent relationship with FEXR. Similarly, FEXR $(-1)$ depicts a positive relationship with MR, i.e. LIR and FEXR at 115.964 and 15.441 percent, respectively. FEXR $(-2)$ has a 5.474 percent positive relationship with FEXR. Agency costs measured by the AUR following the empirical studies of Ang et al. 
(2000) and Gul et al. (2012), shows a negative relationship with MR, that is, both LIR and FEXR, at 5.24 and $0.344 ; 5.076$ and 0.259 percent, respectively. From an agency cost (AUR) perspective, $\mathrm{ROA}_{(-1)}$ and $\mathrm{ROA}_{(-2)}$ have a positive relationship with the AUR of SSA banks at of 24.308 and 0.369 percent, respectively. This conforms to Ang et al. (2000) and (Omolade, Nwosa, Ngalawa, 2019) who averred that it is impossible for a well-performing firm to incur zero agency costs. Furthermore, $\mathrm{DPOR}_{(-1)} ; \mathrm{LIR}_{(-2)}$ and $\mathrm{FEXR}_{(-2)}$ have a positive relationship with agency costs (AUR) at 16.568, 0.3215, 277.53 percent, respectively. In contrast, AUR $_{(-1)}$ and $\mathrm{AUR}_{(-2)}$ negatively relate to AUR at 27.481 and 14.509 percent, respectively.

In conclusion, the $\mathrm{C} 2$ estimate of -0.001 reveals the risks involved $(0.01 \%)$ in enhancing bank performance through dividend policy, agency costs and MR during the period under investigation in SSA even though it is so small. The significance of the VECM was examined using the R-square statistic and revealed that 30.11 percent of the variation in the error associated with the performance of the banking industry can be explained by the dividend policy (DPOR), agency costs (AUR) and MR (interest rate and foreign exchange ratio). The F- statistic value

of $23.655>\mathrm{F}_{0.05}(4,1720)=2.37$ shows that the fitted VECM is statistically significant and hence adequate and reliable in evaluating the relationship between dividend policy, agency costs, MR and banking performance.

\section{Discussion and Implications of the Findings}

The evaluation of the relationship between dividend policy, agency costs, MR and bank performance reveals that there is a long-run co-movement which implies that changes in bank performance are explainable by the other selected variables in the near future. The positive relationship of the foreign exchange rate (MR proxy) with bank performance in SSA as evident from P-VECM, conforms to a priori expectation. This finding implies that a higher rate of the local currency compared to the US Dollar, leads to expansionary monetary policy by a country's apex bank. An economy with an expansionary monetary policy experiences exchange rate depreciation which leads to cheaper domestic goods. Moreover, there will be huge capital inflow that will pass through the financial system of such an economy. In discharging its intermediary activities, the banking sector tends to experience improved performance due to better economic performance which leads to an improved financial system. Most of the countries examined faced a dwindling exchange rate from 2008-2017 which led to exchange rate depreciation; however, this enhances commercial banks' performance. The inverse relationship of the Lending interest rate-LIR with bank performance in SSA as evident from P-VECM, is in tandem with the a priori 
expectation. This finding implies that a higher interest rate discourages banks' customers from taking loans and advances. Loans serve as banks' major asset to trade with, such that when customers are discouraged from borrowing, this negatively impact banks' performance. The monetary policy rate, which is the rate at which the reserve/central bank discounts its firstclass bills, determines the lending rate in an economy. When this rate is high, the lending interest rate also has the tendency to increase and vice versa. However, a lower lending interest rate leads to improved bank performance. The direct relationship between agency costs and bank performance evident from P-VECM implies that the higher the monitoring and bonding costs incurred by banks, the better their performance. The cost function holding the agency costs of firms is such that the marginal benefit is always higher than the marginal cost. In conclusion, dividend policy captured by the dividend payout ratio has a negative relationship with banks' performance from the P-VECM. This implies that SSA banks need to review their choice of dividend policy as the payout policy which is the most common, has had a negative relationship with their performance.

\section{Policy Recommendation}

Based on our findings, it is recommended that the lending interest rate for SSA countries should be reviewed as this has a negative relationship with bank performance. The banking sector in SSA should focus more on endogenous factors and thus review some of their policies as these contribute more significantly to variations in their performance than exogenous factors.

\section{References}

Abadir, K.M., Taylor, A. (1999). On the Definitions of (Co-) integration. Journal of time series analysis, 20 (2), 129-137.

Agyei, S.K., Marfo-Yiadom, E. (2011). Dividend policy and bank performance in Ghana. International Journal of Economics and Finance, 3 (4), 202.

Agyemang Badu, E. (2013). Determinants of Dividend Payout Policy of listed Financial Institutions in Ghana. Research Journal of Finance and Accounting. Retrieved from: http://hdl. handle.net/123456789/88. 
Ajanthan, A. (2013). The relationship between dividend payout and firm profitability: A study of listed hotels and restaurant companies in Sri Lanka. International Journal of Scientific and Research Publications, 3 (6), 1-6.

Akande, J.O., Kwenda, F. (2017). Competitive Condition of Sub-Saharan Africa Commercial Banks. Studia Universitatis Babes-Bolyai Oeconomica, 62 (2), 55-76.

Alencar, L.S., Nakane, M.I. (2004). Bank competition, agency costs, and the performance of the monetary policy. Banco Central do Brasil Working Paper No. 81. Retrieved from: https:// ssrn.com/abstract=926337. DOI: $10.2139 /$ ssrn.926337.

Ang, J.S., Cole, R.A., Lin, J.W. (2000). Agency costs and ownership structure. The Journal of Finance, 55 (1), 81-106.

Asari, F., Baharuddin, N.S., Jusoh, N., Mohamad, Z., Shamsudin, N., Jusoff, K. (2011). A vector error correction model (VECM) approach in explaining the relationship between interest rate and inflation towards exchange rate volatility in Malaysia. World Applied Sciences Journal, 12 (3), 49-56.

Beck, T., Cull, R. (2013). Banking in Africa. World Bank Policy Research Working Paper No. 6684, 1-44.

Brigham, E.F., Ehrhardt, M.C. (2013). Financial management: Theory \& practice: Cengage Learning.

Choi, I. (2001). Unit root tests for panel data. Journal of international money and Finance, 20 (2), 249-272.

Collier, P.M., Agyei-Ampomah, S. (2006). Management Accounting-Risk and Control Strategy: Paper P3. CIMA Learning Systems Strategic Level 2007. Elsevier Science \& Technology.

Damodaran, A. (2012). Investment valuation: Tools and techniques for determining the value of any asset (Vol. 666). John Wiley \& Sons.

Ehikioya, B.I. (2015). An Empirical Investigation of the Impact of Dividend Policy on the Performance of Firms in Developing Economies: Evidence from Listed Firms in Nigeria. International Journal of Finance and Accounting, 4 (5), 245-252.

Ekinci, A. (2016). The Effect of Credit and Market Risk on Bank Performance: Evidence from Turkey. International Journal of Economics and Financial Issues, 6 (2), 427-434.

Feldman, R.J., Schmidt, J. (2000). Interest rate risk: What is it, why banks would want it, and how to evaluate it. The Region (Jul), 16-17.

Flamini, V., Schumacher, M.L., McDonald, M.C.A. (2009). The determinants of commercial bank profitability in Sub-Saharan Africa. International Monetary Fund.

Fredrick, O. (2013). The impact of credit risk management on financial performance of commercial banks in Kenya. DBA Africa Management Review, 3 (1), 22-37. 
Gilb, T. (2002). Risk Management: A practical toolkit for identifying, analyzing and coping with project risks. Paper presented at the International Symposia of the International Council on Systems Engineering (INCOSE).

Groen, J., Kleibergen, F. (2003). Likelihood-Based Cointegration Analysis in Panels of Vector Error Correction Models. Journal of Business and Economic Statistics, 21, 295-318. DOI: 10.1198/073500103288618972.

Gul, S., Sajid, M., Razzaq, N., Afzal, F. (2012). Agency cost, corporate governance and ownership structure (the case of Pakistan). International Journal of Business and Social Science, 3 (9), 221-325.

Hamid, R., Yaqub, M.S., Awan, M.M H. (2016). Antecedents of Dividend Policy: Empirical Evidence from Banking Sector of Pakistan. European Online Journal of Natural and Social Sciences, 5 (2), 263.

Haslem, J.A. (1968). A statistical analysis of the relative profitability of commercial banks. The Journal of finance, 23 (1), 167-176.

Hyndman, R.J., Athanasopoulos, G. (2014). Forecasting: principles and practice. OTexts.

Johansen, S. (1995). Likelihood-based inference in cointegrated vector autoregressive models. Oxford University Press on Demand.

Kargi, H.S. (2011). Credit risk and the performance of Nigerian banks. Ahmadu Bello University, Zaria.

Karkowska, R. (2019). Model of Risk Diversification in the Banking Sector. Folia Oeconomica Stetinensia, 19 (1), 31. DOI: 10.2478/foli-2019-0003.

Kasman, A., Carvallo, O. (2013). Efficiency and risk in Latin American banking: explaining resilience. Emerging Markets Finance and Trade, 49 (2), 105-130.

Levin, A., Lin, C.-F., Chu, C.-S.J. (2002). Unit root tests in panel data: asymptotic and finitesample properties. Journal of econometrics, 108 (1), 1-24.

Li, F., Zou, Y. (2014). The Impact of credit risk management on profitability of commercial banks: A study of Europe. Unpublished MBA Thesis. Sweden: UMEA University.

Ling, F.S., Abdull Mutalip, M., Shahrin, A.R., Othman, M.S. (2007). Dividend policy: evidence from public listed companies in Malaysia.

Maddala, G.S., Wu, S. (1999). A comparative study of unit root tests with panel data and a new simple test. Oxford Bulletin of Economics and statistics, 61 (S1), 631-652.

Mahadevan, R., Asafu-Adjaye, J. (2007). Energy consumption, economic growth and prices: A reassessment using panel VECM for developed and developing countries. Energy Policy, 35 (4), 2481-2490.

Maldajian, C., El Khoury, R. (2014). Determinants of the dividend policy: an empirical study on the Lebanese listed banks. International Journal of Economics and Finance, 6 (4), 240-255. 
Mehta, A., Neukirchen, M., Pfetsch, S., Poppensieker, T. (2012). Managing market risk: Today and tomorrow. McKinsey \& Company McKinsey Working Papers on Risk, 32 (1), 24-36.

Musyoki, D., Kadubo, A.S. (2012). The impact of credit risk management on the financial performance of banks in Kenya for the period. International Journal of Business and Public Management, 2 (2), 72-80.

Nazir, M.S., Saita, H.K., Nawaz, M.M. (2012). The Role of Debt in Reducing Agency Cost: Empirical Evidence from Pakistan. Innova Ciencia, 4 (5), 28-43.

Nimalathasan, B., Pratheepkanth, P. (2012). Systematic Risk Management and Profitability: A Case Study of Selected Financial Institutions in Sri Lanka. Global Journal of Management And Business Research, 12 (17), 1-4. Retrieved from: https://www.journalofbusiness.org/index.php/GJMBR/article/view/812.

Nnadi, M., Wogboroma, N., Kabel, B. (2013). Determinants of dividend policy: Evidence from listed firms in the African stock exchanges. Panoeconomicus, 60 (6), 725-741.

Obalade, A.A., Ebiwonjumi, A., Adaramola, A.O. (2019). Var Modelling of Dynamics of Poverty, Unemployment, Literacy and Per Capita Income in Nigeria. Folia Oeconomica Stetinensia, 19 (1), 73. DOI: 10.2478/foli-2019-0006.

Omolade, A., Nwosa, P., Ngalawa, H. (2019). Monetary Transmission Channel, Oil Price Shock and the Manufacturing Sector in Nigeria. Folia Oeconomica Stetinensia, 19 (1), 89. DOI: 10.2478/foli-2019-0007.

Onanjiri, R., Korankye, T. (2014). Dividend Payout and Performance of Quoted Manufacturing Firms in Ghana. Research Journal of Finance and Accounting, 5 (15), 442-454.

Ouma, O.P. (2012). The relationship between dividend payout and firm performance: a study of listed companies in Kenya. European scientific journal, 8 (9), 199-215.

Santomero, A.M. (1997). Commercial bank risk management: an analysis of the process. Journal of Financial Services Research, 12 (2-3), 83-115.

Sargan, J. (1964). Three-stage least-squares and full maximum likelihood estimates. Econometrica: Journal of the Econometric Society, 77-81.

Singh, M., Davidson III, W.N. (2003). Agency costs, ownership structure and corporate governance mechanisms. Journal of Banking \& Finance, 27 (5), 793-816.

Uwuigbe, U., Jafaru, J., Ajayi, A. (2012). Dividend policy and firm performance: A study of listed firms in Nigeria. Accounting and Management Information Systems, 11 (3), 442-455.

Wang, G.Y. (2010). The impacts of free cash flows and agency costs on firm performance. Journal of service science and management, 3 (4), 408-418. 